\title{
Erratum to: Simultaneous estimation as alternative to independent modeling of tree biomass
}

\author{
Carlos Roberto Sanquetta ${ }^{1}$ - Alexandre Behling ${ }^{1}$ - Ana Paula Dalla Corte ${ }^{1}$. \\ Sylvio Péllico Netto ${ }^{1}$. Ana Beatriz Schikowski ${ }^{1}$ - Maurício Koubay do Amaral ${ }^{1}$
}

Published online: 12 October 2015

(C) INRA and Springer-Verlag France 2015

Erratum to: Annals of Forest Science

DOI 10.1007/s13595-015-0497-2

The last author's name was incomplete in the original publication. The name is correct as listed in this erratum. The original publication has been updated accordingly.

The online version of the original article can be found at http://dx.doi.org/ 10.1007/s13595-015-0497-2.

\footnotetext{
Carlos Roberto Sanquetta carlos_sanquetta@hotmail.com

Forest Sciences Department, Forest Inventory Laboratory - Center for Excellence in Biomass Carbon Fixation Studies (BIOFIX), Federal University of Paraná, Av. Pref. Lothário Meissner, 900 Jardim Botânico - Campus III, 80210-170 Curitiba, Paraná, Brazil
} 